\title{
Relationships between anthropometric measurements, leptin and IGF-1 levels in Turkish healthy newborns
}

\section{Sağlıklı Türk yenidoğanlarda antropometrik ölçümlerin leptin ve IGF-1 seviyeleriyle ilişkisi}

\author{
Sacide Karakaş ${ }^{1}$, Ayfer Metin Tellioğlu ${ }^{1}$, Güzel Dişcigil ${ }^{2}$, Aslıhan B. Karul ${ }^{3}$, Münevver Türkmen ${ }^{4}$
}

\begin{abstract}
Objective: The aim of the present study is to determine anthropometric measurements of a group of healthy newborns and evaluate their association with the serum levels of leptin and insulin-like growth factor 1(IGF-1).

Methods: Extremity lengths, skinfold thickness, body circumference measurements of 113 heathy newborns were taken by appropriate methods. Of the total 113 newborns, 55 were male and 58 were female. Serum leptin and IGF1 levels were measured.
\end{abstract}

Results: Leptin levels had moderately positive correlations with body mass index (BMI), weight and suprailiac skinfold thickness $(p<0.05)$. There was no significant relationship between anthropometric measurements and IGF-1 levels ( $p>0.05)$.

Conclusion: Anthropometric measurements of newborns will be of guidance for the growth and development of their future life. J Clin Exp Invest 2015; 6 (3): 214-219

Key words: Anthropometry, newborn, leptin, insulin-like growth factor 1 (IGF-1)

\section{INTRODUCTION}

Anthropometric measurements are non-invasive, easy to apply, and inexpensive techniques which help to evaluate body composition of all ages including newborns [1].

Abnormalities of limbs are important features of some syndromes recognizable at birth [2,3]. Measurements of skinfold thickness has shown to be a convenient and non-invasive method for the assessment of total body fat [4]. Newborn measurements of some anthropometric indices will be guidance for the growth and development of the future adult life. For instance, somatic growth and malnutrition as-

\section{ÖZET}

Amaç: Bu çalışmanın amacı, sağlıklı yenidoğanların antropometrik ölçümlerini yapmak ve ölçümlerin serum leptin ve insulin benzeri büyüme faktörü $1($ IGF-1) düzeyleriyle ilişkisini araştırmaktır.

Yöntemler: Toplam 113(55 erkek, 58 kız) sağlıklı yenidoğanda, ekstremite uzunlukları, deri kıvrım kalınlığı, vücut çevre ölçümleri uygun yöntemler kullanılarak ölçüldü. Serum leptin ve IGF-1 seviyelerine bakıldı.

Bulgular: Antropometrik ölçümlerden vücut kitle indeksi, vücut ağırlığı ve suprailiac deri kıvrım kalınlığı ile serum leptin seviyesi arasında orta düzeyde pozitif korelasyon saptandı $(p<0.05)$. IGF seviyesi ve antropometrik ölçüm sonuçları arasında anlamlı bir ilişki saptanmadı ( $p>0.05)$.

Sonuç: Bebeklerin antropometrik ölçümleri gelecekteki büyüme ve gelişme düzeyleri konusunda rehberlik edecektir. Leptin büyüme üzerine etkili bir hormondur.

Anahtar kelimeler: antropometri, yenidoğan, leptin, insulin benzeri büyüme faktörü 1(IGF-1)

sessments are possible by body weight, height and head circumference measurements [5].

Leptin is secreted from adipose tissue and plays an important role in obesity. During pregnancy, leptin is mainly produced by maternal adipose tissue, fetal adipose tissue and placenta. Early studies have shown that leptin is found in significant concentrations in umbilical cord blood and its effect to infant growth has attracted significant interest [6]. A number of studies using leptin levels in cord blood in correlation with neonatal anthropometric measures at birth such as birth weight, birth length, head and abdominal circumference [7].

\footnotetext{
${ }^{1}$ Adnan Menderes University, School of Medicine, Department of Anatomy, Aydın, Turkey

${ }^{2}$ Adnan Menderes University, School of Medicine, Department of Family Medicine, Aydın, Turkey

${ }^{3}$ Adnan Menderes University, School of Medicine, Department of Biochemistry, Aydın, Turkey

${ }^{4}$ Adnan Menderes University, School of Medicine, Department of Pediatrics, Aydın, Turkey
}

Correspondence: Ayfer Metin Telllioğlu,

Adnan Menderes Üniversitesi Tıp Fakültesi Anatomi AD, Aydın, Türkiye Email: ayfertellioglu@yahoo.com

Received: 03.06.2015, Accepted: 18.08.2015

Copyright @ JCEI / Journal of Clinical and Experimental Investigations 2015, All rights reserved 
Likewise insulin-like growth factor 1 (IGF-I) has a major role in the regulation of human growth and it was found to be correlated with fat-free mass $[8,9]$. Serum IGF-1 levels increase as the child grows, reach a peak value at puberty, and decrease with aging $[9,10]$. There is no data about correlation of leptin and IGF-1 levels with body compositions of Turkish newborns to our knowledge. Our goals are to provide data for anthropometric measurements of the Turkish normal newborns and to determine a possible correlation between anthropometric measurements and serum levels of leptin and IGF-1.

\section{METHODS}

A total of 113 newborns from the department of Child Health and Diseases of Adnan Menderes University Medical Faculty and Aydın Maternity Hospital were included in this study. Of the total 55 were male and 58 were female. All newborns included in the study were healthy, over 3,000 gr and were born between 38-40 weeks of gestation.

Prior to commencement of the study, approval was obtained from the Ministry of Health and local ethical committee. Written consents were obtained from the parents of the newborns. Measurements were carried out by trained personnel within 24 hours after birth. Newborns with hereditary disease, physical defects, premature birth, and birth weight lower than 3,000 grams were excluded from the study.

\section{Anthropometric measurements}

All the measurements were done while the newborn has been lying supine on the examining table and on the right side of its body. Lengths of total arm, upper arm, forearm, hand, total leg, upper leg, lower leg, foot and trunk were measured using a sliding caliper (Harpenden, Holtain, Bicondylar vernier, UK). Research staffs received specific training in the use of measuring equipment, which was calibrated each morning before measurements were taken according to Hall et al. Each baby was measured 30 minutes after being feed [11]. Birth weight (gr), length $(\mathrm{cm})$, circumference measurements $(\mathrm{cm})$, and skinfold thicknesses $(\mathrm{mm})$ were recorded. Newborn anthropometric measurements were obtained within 24 hours of delivery. All the newborns were weighed naked on a spring type of weighing.

Weight: was measured to the nearest $0.01 \mathrm{~kg}$ by use of a Weylux beam balance (CMS Weighing Equipment Ltd, London, UK).

\section{Circumference measurements}

Circumference were measured at 3 sites (chest, mid-arm and abdomen) using an inelastic tape measure by one investigator. The measurements were taken during quiet respiration at least 30 minutes after feeding except for those who had not been commenced on enteral feeding.

\section{Skinfold thicknesses}

Skinfolds were measured at 6 sites to the nearest $0.1 \mathrm{~mm}$ (biceps, triceps, subscapular, abdominal, suprailiac, thigh) using a Holtain caliper by one investigator. Anthropometric data were recorded using a standardized data report form by one investigator [11,12].

\section{Serum leptin and IGF-1}

Serum leptin and IGF-1 were obtained from a cannulated with directly after birth. Venous blood was drawn immediately after birth from umbilical cord blood vessels by one investigator. After separating the serums from blood, serum samples were stored at $-80^{\circ} \mathrm{C}$ until performing the analysis. Serum leptin measurements were done by using Leptin Serum EASIA(Enzyme Amplified Sensitivity Immunoassay) (Cat. No: KAP2281; Biosource Europe S.A; Nivelles, Belgium). IGF-1 measurements were done by using IGF-1-ELISA (Enzyme-Linked ImmunoSorbent Assay) (Cat No: KAPB 2010 Biosource Europe S.A; Nivelles, Belgium) [13].

\section{Statistical Analysis}

The Kolmogorov-Smirnov test was used to assess the normality of numeric variables. For the numeric variables that were normally distributed, comparison between two groups was made by the independent sample $t$ test. For the non-normally distributed variables, comparison between two groups was made by the Mann-Whitney $U$ test. The results were expressed as mean plus minus standard deviation or median (25-75 percentiles). Statistical significance was defined as $p<0.05$. The correlation analysis was used to determine the relationship among the quantitative variables.

\section{RESULTS}

Our sample consists of 113 (55 male, 58 female) healthy term newborns in Aydin, Turkey.

\section{Extremity lengths}

Torso and upper leg length of girls were longer than boys whereas leptin levels were higher in boys. Details are shown on Table 1,4. 


\section{Circumferences and skinfold thicknesses}

There was no significant difference between male and female newborns in circumferences measurements and skinfold thicknesses ( $p>0.05)$ Table 2 and 3.

\section{Leptin and IGF-1}

Leptin levels were higher in boys $(p=0.036)$. There was no significant difference in the value of IGF-1 between male and female $(p>0.05)$. Details are shown on Table 4.

Leptin levels were positively correlated with BMI, weight and suprailiac skinfold thickness Details are shown on Table 5. There was no correlation with anthropometric measurements and IGF-1 levels (Table 4).

Table 1. Extremity length measurements

\begin{tabular}{|c|c|c|c|c|c|c|c|}
\hline & \multicolumn{3}{|c|}{ Male $(n=55)$} & \multicolumn{3}{|c|}{ Female $(n=58)$} & \multirow[b]{2}{*}{$\mathbf{p}$} \\
\hline & $\begin{array}{c}\text { Mean } \pm S D, \text { Median } \\
(25-75 \text { pp })\end{array}$ & Min & Max & $\begin{array}{l}\text { Mean } \pm S D, \text { Median } \\
\text { (25-75 percentiles) }\end{array}$ & Min & Max & \\
\hline Height (cm) & $50(50-51)$ & 45.0 & 54.0 & $50(50-50)$ & 48.0 & 55.0 & 0.694 \\
\hline Weight (gr) & $3472 \pm 324$ & 3010 & 4300 & $3423 \pm 301$ & 3000 & 4480 & 0.414 \\
\hline Sternal length (mm) & $53.56 \pm 8.18$ & 40.0 & 77.0 & $51.14 \pm 7.93$ & 25.6 & 67.0 & 0.113 \\
\hline Torso length (mm) & $15.60(15.20-16.80)$ & 12.5 & 18.5 & $16.80(15.35-17.529)$ & 12.6 & 18.8 & 0.016 \\
\hline Total upper extremity (cm) & $16.25(15.37-18.12)$ & 12.2 & 20.3 & 15.15(13.64-18.77) & 11.5 & 22.0 & 0.440 \\
\hline Upper arm length (mm) & $86.01 \pm 10.05$ & 66.0 & 104.0 & $85.30 \pm 9.04$ & 61.0 & 98.0 & 0.696 \\
\hline Lower arm length (mm) & $76.3(71.1-79.2)$ & 58.0 & 90.0 & 77.20 (72.95-80.32) & 54.0 & 89.3 & 0.361 \\
\hline Hand length (mm) & $53.9(50.0-6180)$ & 42.0 & 67.0 & 54.20 (51.95-57.50) & 37.0 & 69.9 & 0.877 \\
\hline Total lower extremity (cm) & $19.6 \pm 1.76$ & 15.0 & 23.0 & $19.53 \pm 1.81$ & 14.0 & 24.0 & 0.745 \\
\hline Upper leg length (mm) & $107.0(93.0-115.6)$ & 73.0 & 136.0 & $112.00(105.62-118.4)$ & 72.0 & 135.0 & 0.015 \\
\hline Lower leg length (mm) & $108.4(97.0-12360)$ & 63.0 & 138.3 & $118.0(105.0-124.2)$ & 66.0 & 142.2 & 0.122 \\
\hline Foot length (mm) & $73.12 \pm 6.28$ & 60.0 & 87.1 & $74.34 \pm 5.55$ & 60.0 & 83.4 & 0.274 \\
\hline
\end{tabular}

SD: Standard deviation, Min: Minimum, Max: Maximum

Table 2. Skinfold thicknesses

\begin{tabular}{|c|c|c|c|c|c|c|c|}
\hline & \multicolumn{3}{|l|}{ Male $(n=55)$} & \multicolumn{3}{|c|}{ Female $(n=58)$} & \multirow{2}{*}{ p } \\
\hline & Median (25-75 percentiles) & Min & Max & Median (25-75 percentiles) & Min & Max & \\
\hline Triceps (mm) & $5.0(4.0-6.0)$ & 2.5 & 8.0 & $5.0(4.5-5.5)$ & 3.0 & 7.0 & 0.924 \\
\hline Biceps (mm) & $4.0(3.0-4.1)$ & 1.1 & 6.0 & $3.5(3.0-4.5)$ & 2.2 & 6.0 & 0.785 \\
\hline Subscapular (mm) & $4.5(4.0-5.0)$ & 2.0 & 8.0 & $5.0(4.0-5.5)$ & 2.0 & 8.0 & 0.083 \\
\hline Suprailiac (mm) & $3.1(2.5-4.2)$ & 1.5 & 7.5 & $3.0(2.8-3.5)$ & 1.5 & 7.0 & 0.135 \\
\hline Thigh (mm) & $6.00(5.0-7.0)$ & 3.0 & 13.0 & $6.0(5.0-6.2)$ & 3.5 & 9.0 & 0.901 \\
\hline Abdomen (mm) & $4.0(3.0-4.5)$ & 1.5 & 6.0 & $4.0(3.0-4.0)$ & 2.0 & 6.0 & 0.538 \\
\hline
\end{tabular}

Min: Minimum, Max: Maximum

Table 3. Circumference measurements

\begin{tabular}{|c|c|c|c|c|c|c|c|}
\hline & \multicolumn{3}{|l|}{ Male $(n=55)$} & \multicolumn{3}{|c|}{ Female $(n=58)$} & \multirow{2}{*}{$\mathbf{p}$} \\
\hline & Median (25-75 percentiles) & Min & Max & Median (25-75 percentiles) & Min & Max & \\
\hline Occipito-frontal (cm) & $35.0(34.0-36.0)$ & 32.0 & 37.0 & $33.5(34.0-35.0)$ & 32.0 & 38.50 & 0.198 \\
\hline Chest $(\mathrm{cm})$ & $34.0(33.0-35.0)$ & 30.0 & 37.0 & $33.0(32.8-34.5)$ & 31.0 & 37.00 & 0.272 \\
\hline Upper arm (cm) & $11.0(10.5-12.0)$ & 8.5 & 13.0 & $11.0(10.4-11.5)$ & 9.0 & 12.00 & 0.063 \\
\hline Abdominal (cm) & $31.0(30.0-33.0)$ & 28.0 & 36.0 & $31.0(31.0-3200)$ & 22.0 & 34.00 & 0.970 \\
\hline
\end{tabular}

Min: Minimum, Max: Maximum 
Table 4. Serum leptin and IGF-1 levels

\begin{tabular}{|c|c|c|c|c|c|c|c|}
\hline & \multicolumn{3}{|c|}{ Male $(n=55)$} & \multicolumn{3}{|c|}{ Female $(n=58)$} & \multirow[b]{2}{*}{$\mathbf{p}$} \\
\hline & $\begin{array}{c}\text { Mean } \pm \text { SD, } \\
\text { Median (25-75 percentiles) }\end{array}$ & Min & Max & $\begin{array}{c}\text { Mean } \pm \text { SD, } \\
\text { Median (25-75 percentiles) }\end{array}$ & Min & Max & \\
\hline Leptin (ng/mL) & $13.2(11.2-14.5)$ & 3.2 & 37.1 & $12.1(11.1-13.4)$ & 2.6 & 14.6 & 0.036 \\
\hline IGF-1 & $179.6 \pm 88.4$ & 54.1 & 472.7 & $194.4 \pm 98.1$ & 63.3 & 461.9 & 0.416 \\
\hline
\end{tabular}

IGF-1: Insulin-like growth factor 1, Sd: Standard deviation, Min: Minimum, Max: Maximum

Table 5. Correlation with leptin and IGF-1 values and skinfold thickness, circumference measurements

\begin{tabular}{|c|c|c|c|c|c|}
\hline & \multicolumn{2}{|c|}{ Leptin } & & \multicolumn{2}{|c|}{ IGF-1 } \\
\hline & $\mathbf{r}$ & $\mathbf{p}$ & & $\mathbf{r}$ & $\mathbf{p}$ \\
\hline Body Mass Index $\left(\mathrm{kg} / \mathrm{m}^{2}\right)$ & 0.530 & 0.001 & Lover arm length (mm) & 0.202 & 0.032 \\
\hline Weight & 0.666 & 0.001 & Hand length (mm) & 0.227 & 0.016 \\
\hline Triceps skinfold thickness & 0.311 & 0.001 & Lower leg length (mm) & 0283 & 0.002 \\
\hline Biceps skinfold thickness & 0.304 & 0.001 & Foot length $(\mathrm{mm})$ & 0.232 & 0.013 \\
\hline Suprailiac skinfold thickness & 0.666 & 0.002 & Abdominal circumference & 0.221 & 0.019 \\
\hline Thigh skinfold thickness & 0.263 & 0.005 & Suprailiac skinfold thickness & 0.246 & 0.009 \\
\hline Abdominal skinfold thickness & 0.197 & 0.003 & Thigh skinfold thickness & 0.197 & 0.036 \\
\hline Occipital-frontal circumference(cm) & 0.340 & 0.001 & & & \\
\hline Chest circumference $(\mathrm{cm})$ & 0.374 & 0.001 & & & \\
\hline Upper arm circumference & 0.374 & 0.001 & & & \\
\hline Abdominal circumference & 0.433 & 0.001 & & & \\
\hline
\end{tabular}

IGF-1: Insulin-like growth factor

\section{DISCUSSION}

Our results reveal that there were correlations between leptin levels and some anthropometric measurements. Furthermore there are several anthropometric measurement differences in terms of gender in addition to leptin and IGF-1. There is no literature to our knowledge, including comprehensive evaluation about association of anthropometric measurements with leptin and IGF-1 in Turkish newborns.

An increase in the levels of leptin increases energy expenditure. Because the energy balance in a growing fetus must be positive, a low concentration of serum leptin is physiologically suitable for fetal growth. Some investigators indicate that there is no difference between gender and leptin levels [14-17]. However we found that boys had higher leptin levels than girls. In contrast to our results, Savino F. et al. report that leptin values were higher in girls [18].

Many studies have found positive correlation between leptin and body mass index (BMI), weight, height, skinfold thicknesses and circumference measurements $[19,20,21,22,23]$. We also found positive correlation between leptin levels and birth weight and BMI in addition to some skinfold thickness measurements. Pathmaperuma et al. did not find any correlation with IGF-1 levels and any of the anthropometric indices which is similar to our results [24].

In general, upper extremities in newborns are longer than the trunk and lower extremities. In newborns, it is reported that the forearms are longer than the arms. Male infants have longer forearms and arms compared to females [25]. In addition Fok et al indicate that there is no difference between torso length among boys and girls [26]. In contrast to these studies we did not find any difference between boys and girls in terms of arm lengths whereas torso length was higher in girls. Hadler et al. did not find any difference between upper extremity lengths of boys and girls [27].

Laccerda reported that they did not find any difference between boys and girls which is similar to our results [28]. No difference was found for chest circumference between girls and boys [24,27]. However many studies have found positive correlation between chest circumference and weight $[26,29,30]$. 
We also found that there was positive correlation between height and chest circumference whereas chest, upper arm and abdominal circumference were positively correlated with weight. In addition many studies report that upper arm circumference positively correlated with weight $[31,32,33]$. There is conflicting results about upper arm circumference no difference among boys and girls. There are many studies which did not find any difference between boys and girls $[26,29]$ There is also conflicting results about abdominal circumference and gender differences [34]. We did not find any difference between boys and girls.

Some studies indicate that gender differences among skinfold thickness are related to hormonal differences between boys and girls [35].

Furthermore many studies mention that skinfold thicknesses of girls are higher than boys in each gestational age [36]. However, there are some studies, which did not find any difference for triceps and subscapular skinfold thicknesses which is similar to our results [35].

Anthropometric measurements of newborns and gender differences were widely studied even though there is no comprehensive data about Turkish newborns. However there is no data to our knowledge about association of anthropometric measurements and leptin and IGF-1 levels of newborns. We concluded that there are several anthropometric measurement differences in newborns in terms of gender. Furthermore there is association between leptin and IGF-1 levels and some anthropometric measurements in addition to gender.

\section{REFERENCES}

1. Hayran O. Çocuklarda beslenme ve büyümenin değerlendirilmesi açısından antropometrik ölçümlerin anlamı ve yorumu. Beslenme ve Diet Dergisi 1990;19:237243.

2. Madhulika Kabra SK, Barar V, Puriot A et al. Upper and lower limb standards in newborn. Indian Pediatr 1989;26:667-670.

3. Puliyel JM. Upper and Lower Limb Standards in Newborns. Indian Pediatr 1990;27:643-645.

4. Schmelzle HR, Fusch C. Body fat in neonates and young infants: validation of skinfold thickness versus dual-energy x-ray absorptiometry. Am J Clin Nutr 2002;76:1096-1100.

5. WHO. Physical Status: The Use and Interpretation of Anthropometry. Report of a Technical Committee. GenevaTechnical Report Series 1995; No:854.
6. Tung WK, Lin SJ, Hwang YS, et al. Association of cord plasma leptin with birth size in term newborns. Pediatr Neonatol 2009;50:255-260.

7. Tsai PJ, Yu CH, Hsu SP, et al. Cord plasma concentrations of adiponectin and leptin in healthy term neonates: positive correlation with birthweight and neonatal adiposity. Clinical Endocrinol 2004;61:88-93.

8. Ong K, Kratzsch J, Kiess W, et al. Circulating IGF-I levels in childhood are related to both current body composition and early postnatal growth rate. J Clin Endocrinol Metab 2002;87:1041-1044.

9. Yüksel B, Özbek MN, Mungan NÖ, et al. Serum IGF1 and IGFBP-3 levels in healthy children between 0 and 6 years of age. J Clin Res Pediatr Endocrinol 2011;3:84-88.

10. Nasr MR, Ebrahim NA, Ramadan MS, et al. Growth pattern in children with beta-thalassemia major and its relation with serum ferritin, IGF1 and IGFBP3. J Clin Exp Invest 2012;3:157-163.

11. Hall JG, Foster Iskenius UG, Allanson JE. Handbook Of Normal Physical Measurements, New York: Oxford University Press, 1989.

12. Heyward VH, Atolarczyk LM. Applied Body Composition Assessment. Champaign: Human Kinetics, 1996:1-221

13. Yoshioka T, Kawada K, Shimada T, et al. Lipid peroxidation in maternal and cord blood and protective mechanism against activated-oxygen toxicity in the blood. Am J Obstet Gynecol 1979;135:372-376.

14. Kratsch J, Schubring C, Stitzel B, et al. Inverse changes in the serum levels of the soluble leptin receptor and leptin in neonates- relations to anthropometric data. J Clin Endocrinol Metab 2005;90:2212-2217.

15. Yildiz L, Avci B, Ingeç M. Umbilical cord and maternal blood leptin concentrations in Intrauterine growth retardation. Clin Chem Lab Med 2002;40:1114-1117.

16. Yeung LP, Wong AC, Wang X, et al. Different relationship between anthropometric markers and umbilical cord plasma leptin in asian and caucasian neonates. Pediatr Res 2003;53:1019-1024.

17. Savino F, Fissore MF, Grassino EC, et al. Ghrelin, leptin and IGF-1 in breast-fed and formula-fed infants in the first years of life. Acta Paediatr 2005;94:531537.

18. LakhoGR, Haq Z, Chundrigar T, et al. Cord blood leptin levels in Pakistani newborns: relationship with birth weight, length and occipitofrontal circumference. J Coll Physicians Surg Pak 2006;16:393-395.

19. Christou H, Connors JM, Ziotopoulou M, et al. Cord blood leptin and insulin-like growth factor levels are Independet predictors of fetal growth. J Clin Endocrinol Metab 2001;86:935-938.

20. Cho GJ, Yoo SW, Hong SC, et al. Correlations between umbilical and maternal serum resistin levels and neonatal birth weight.Acta Obstet Gynecol Scand 2006;85:1051-1056. 
21. Pathmaperuma AN, Tennekoon KH, Senanayake L, et al. Maternal and cord blood levels of insulin-like growth factors-I and-II and insulin-like growth factor binding protein-1: correlation with birth weight and maternal anthropometric indices. Ceylon Med J 2007;52:48-52.

22. Tennekoon KH, Poopalapillai J, Karunanayake AG, et al. Association of cord blood leptin, soluble leptin receptor, insulin-like growth factor-I and insulinlike growth factor-binding protein-1 on birth indices in healthy full term newborns. Horm Res Paediatr 2014;81:232-238.

23. Rohrmann S, Sutcliffe CG, Bienstock JL, et al. Racial variation in sex steroid hormones and the insulin-like growth factor axis in umbilical cord blood of male neonates. Cancer Epidemiol Biomarkers Prev 2009;18:1484-1491.

24. Taeusch H W. Initial Evaluations: History and Physical Examination of Newborn. In: Taeusch HW, Ballord RA, Avery ME. Diseases of Newborn. Philadelphia. W.B. Saunders Company 1991:207-224.

25. Fok TF, Hon KL, Wong E, et al. Trunk Anthropometry of Hong Kong Chinese Infants. Early Hum Dev 2005;81:781-790.

26. Halder D, Dharap AS, Than M. Normal values for total hand length, palm length and middle finger length in malaysian newborns from 34-42 weeks of gestation. Anthropol Anz 1999;57:69-75.

27. Laccerda, C. A. M. Foot length growth related to crown-rump length gestational age and weigth in human staged fresh fetuses. Surg Radiol Anatomy 1990;12:103-107.

28. Sreeramareddy CT, Chuni N, Patil R,et al. Anthropometric surrogate to Identify low birth weight nepalese newborns: a hospital-based study. BMC Pediatrics 2008;8:1-8.

29. Samal GC, Swain AK. Calf circumference as an alternative to birth weight for Identification of low birth weight babies. Indian Pediatrics 2001;38:275-277.

30. Ahmed FU, Karim E, Bhuiyan SN. Mid-arm circumference at birth as predictor of low birth weight and neonatal mortality. J Biosoc Sci 2000;32:487-493.

31. Das JC, Afroze A, Khanam ST, et al. Mid-arm circumference: an alternative measure for screening low birth weight babies. Bangladesh Med Res Counc Bull 2005;31:1-6.

32. Iroha EO, Ezeaka VC, Akinsulie AO, et al. Maternal HIV Infection and intrauterine growth: a prospective study in Lagos, Nigeria. West Afr J Med 2007;26:121125.

33. Şehla İhsan. 9-72 aylık çocuklarda antropometrik ölçümler ve antropometrik ölçümlere etki eden parametrelerin araştırılması. Uzmanlık Tezi, T.C. Sağlık Bakanlığı Bakırköy Dr. Sadi Konuk Eğitim ve Araştırma Hastanesi, İstanbul,2006:1-84.

34. Rodriguez G, Samper M, Olivares J, et al. Skinfold measurements at birth: sex and anthropometric influence. Arch Dis Child Fetal Neonatal Ed 2005;90:273275.

35. Guihard-Costa A M, Grange G, Larroche JC, et al. Sexual differences in anthropometric measurements in French newborns. Biol Neonate 1997;72:156-164.

36. Shah D, Sachdev HP, Gupta R, et al. Secular change in newborn adiposity in an urban hospital. Indian Pediatrics 2004;41:1-5. 